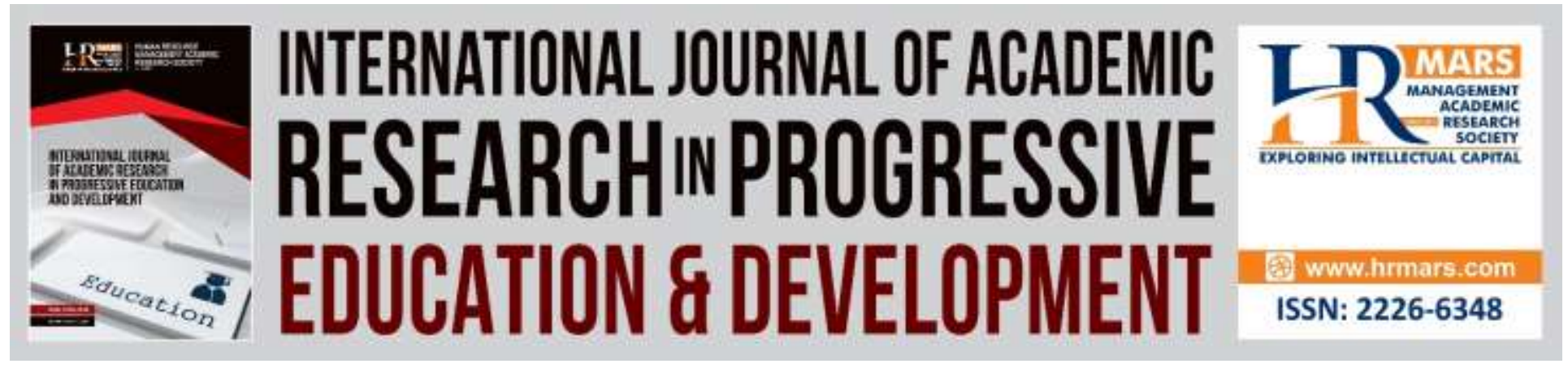

\title{
PICTOWORD GAME: Improve Compound Nouns Among ESL Students
}

Faten Hanani Fauzi, Azlina Abd Aziz

To Link this Article: http://dx.doi.org/10.6007/IJARPED/v9-i2/7184

DOI:10.6007/IJARPED/v9-i2/7184

Received: 27 February 2020, Revised: 30 March 2020, Accepted: 15 April 2020

Published Online: 30 April 2020

In-Text Citation: (Fauzi \& Aziz, 2020)

To Cite this Article: Fauzi, F. H., \& Aziz, A. A. (2020). PICTOWORD GAME: Improve Compound Nouns Among ESL Students. International Journal of Academic Research in Progressive Eduacation and Development,9(2), 3554.

Copyright: (C) 2020 The Author(s)

Published by Human Resource Management Academic Research Society (www.hrmars.com)

This article is published under the Creative Commons Attribution (CC BY 4.0) license. Anyone may reproduce, distribute, translate and create derivative works of this article (for both commercial and non-commercial purposes), subject to full attribution to the original publication and authors. The full terms of this license may be seen at: $\underline{\text { http://creativecommons.org/licences/by/4.0/legalcode }}$

\section{Vol. 9(2) 2020, Pg. 35 - 54}

Full Terms \& Conditions of access and use can be found at http://hrmars.com/index.php/pages/detail/publication-ethics 


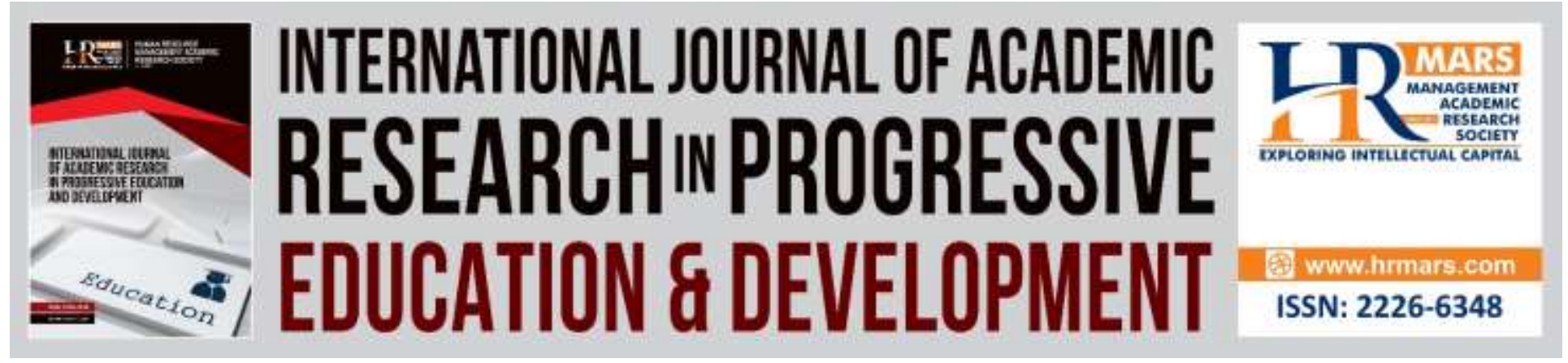

\title{
PICTOWORD GAME: Improve Compound Nouns Among ESL Students
}

\author{
Faten Hanani Fauzi \\ SK Jalan 3, Jalan 3/4 Seksyen 3, 43650 Bandar Baru Bangi, Selangor, Malaysia \\ Email: fatenhanani3893@yahoo.com
}

Azlina Abd Aziz

Faculty of Education, Universiti Kebangsaan Malaysia (UKM),43600 Bangi, Selangor, Malaysia.

Email: azlina1@ukm.edu.my

\begin{abstract}
The importance of integrating mobile technology in assisting language learning is becoming a trending in the learning of ESL. Apple store and Google Play are online applications, which people can easily downloaded games and can be used as an educational tool. Therefore, this is an action research focuses on improving the pupils' spelling skills in compound nouns words through the usage of Pictoword Game. The participants of this research were thirty-five Year 5 pupils from an urban school in Bandar Baru Bangi, Selangor. The Pictoword Game had been used as intervention method in improving pupils' spelling compound nouns. Steps in the implementation were Spelling Bee games as pre-test, "Two Pictures One Word" games from the Pictoword Game, and then proceed with two crossword puzzles as post-test. The findings of the research were analysed mixed method using the Triangulation of spelling document analysis, observation's checklist and Emoji survey. The findings indicated that there had been an improvement in the participants' spelling performance in compound nouns after the intervention and gave positive opinions concerning the use of the game application. Apart from that, this research has limitations to be furthered to verify the long run effectiveness as the words provided already programmed in the game application.
\end{abstract}

Keywords: Game Application, Spelling, Primary Students, Nouns, Improvement.

\section{Introduction}

The new curriculum Primary School Standard Curriculum (KSSR) had been implemented in Malaysian Education System in 2011 with the aim to enhance the pupil's English language (Mohamed, 2007). According to Year 5 KSSR's English document standard, the aim of the English program is to make pupils learn the language in order to help them to use the language in their everyday lives, to continue their studies and to work (Ministry of Education, 2012). Harmer (2007) 
clarified that the language shows not only new meanings, but also how words are written and articulated. Westwood (2014) claimed that it was quite difficult to teach spelling, considering that thousands of words were written in English.

According to Carreker (2005), using a multisensory memory strategy gives students chances to practice spelling the word repeatedly. If the students cannot write well they were unable to write properly, students may encounter writing problems and may experience difficulties in a number of aspects of writing skills like correct grammar usage, punctuation, capitalisation, orthodoxy and some of the basic and initiating elements of teaching, which also constitute an unacceptable piece of work both for ESL teachers and students (Ghabool \& Kashef, 2012). Hence, the spelling problem may affect the writing skills because when the students write down the words wrongly, it may lead in the wrong spelling. Meaning that, they will implement the knowledge that they know wrongly in their learning process. It will totally affect their understanding of the words and get confuse with the words that they learned. It is called as misspelled the words as mentioned by (Lanir, 2011).

Bahagian Pembangunan Kurikulum (2011) stated that KSSR curriculum introduces pupils to the process of writing sample compositions but the mechanics of writing such as spelling, punctuation and grammar checking is also emphasized. Hence, researcher focused on improving the pupils spelling on compound noun which were commonly required in a writing exercises by implementing teaching spelling using picture incorporating in games.

In the research entitled "Investigating Spelling Errors in a Malaysian Learner Corpus", Botley, Hakim, and Dillah (2016) identified spelling errors and can be divided firstly into Mechanical Errors, which includes Punctuation, Typographic, Confusibles and Dyslexic errors. Secondly, there are the Mis-spellings, which are divided into Mispronunciation Errors and Written Misencodings. Written Misencodings in turn can be further divided into Interlingual and Intralingual. Based on the spelling bee activity in the class, researcher noticed the errors that the pupils did were related to the both 'mechanical error' and 'mis - spellings'. Elaboration about the errors pupils made were portrayed in the table below:

\section{Literature Review}

Scaffolding is a teaching strategy filled with the notion that students have a great deal of prior knowledge in an educational setting. Some of this information might not be precise, but it is important to make scaffolding as an efficient teaching technique based on something that a student already understands (Byrnes, 2001). It is known as the beginner who approaches or picks over the skills and knowledge and is responsible for its own learning (Mamour, 2008). Scaffolding is benefit to the learner by (a) clarity of the path, (b) identifying tasks ' goals, (c) assessing expectations, (e) leading them to relevant sources, (f) reducing confusion, surprise and deceit, (g) providing efficiency and (h) building momentum (Mamour, 2008).

Holton and Clarke (2006) distinguish scaffolding in two aspects in their theory of scaffolding. The first one is called the domain and the following one is the agency. The scope is further split into 
two categories: logical and heuristic. The teacher scaffold to provide conceptual understanding and design is called conceptual scaffolding and a scaffolding to find ways to solve a learning problem. They also suggested three types of scaffolding: expert, reciprocal and self-scaffolding, as far as the teachers are concerned. The Scaffolds provided by a teacher is expert scaffolding. On the contrary the mutual scaffolding and ultimately self-scaffolding of a student working in a school, either face to face or online, is when a student is in a condition where he or she has the ability to scaffold his or her own self. In the combined scaffolding technique using mobile game in the study these 3 types of agency scaffolding (expert, reciprocal and auto scaffolding) are used.

The Piagetian theory which maintains that spelling skills and techniques learned follow a series of qualitatively distincted phases where different sources of comprehension are used (Templeton, 2002) Focusing on different language mechanisms involved in the development of spelling, one common interpretation of spelling is based on the Piagetian theory. The intellectual capacity of learners originated by the contact and communication between community and more competent peers and adults, theoretical social-constructivist theory such as Vygotsky (1978). In accordance with the opinion of Vygotsky, one of the goals of the present study are to make students aware of the mental spelling at higher levels, such as visual imagery, that they can use effectively to improve their spelling skills. Moreover, Gardner's (2004) theory of multiple intelligences, which included the use of a digital imaging system, was also considered by the scholar as aiding the spelling strategies and providing pupils to express their feelings. Gardner (2004) believed that if students have the opportunity to learn from their talents, they would have greater progress in all subject areas, including the development of basic skills.

Playing spelling language game can be presented as a kind of prize after learning, which allows teachers to motivate learners to step forward (Miller and Pound, 2010). Piaget also supported the significance of playing due to its contribution to the development of problem solving, creativity, and communication, which happens naturally in the process of playing language games (Sylvan, 2012). the combination of 'Pictoword' game with the spelling activity have created fun and meaningful to the pupils as DuBois, Erickson and Jacobs (2007) said that spelling games become more fun and engaging for the teacher and students. Through games the students become active learners as Dogg (2012) mentioned that games could create a comfortable and friendly atmosphere. Games are highly motivating because they are amusing and interesting. They can be used to give practice in all language skills and be used to practice many types of communication (Ersoz 2010). Thus, the combination of 'Pictoword' game with the spelling activity have created fun and meaningful to the pupils as DuBois, Erickson and Jacobs (2007) said that spelling games become more fun and engaging for the teacher and students

Vocabulary learning, easily transformed into boring rote memorization, has also been suggested to be a more pleasurable and efficient activity online (Prensky, 2002). In general, online vocabulary learning resources are already quite popular among children, although most of them are simple mechanical instruction (Wood, 2015). Sylvan (2012) also stated that the online game played a role to increase higher vocabulary performances among Swedish children among aged 11 to 12 years old. 
Studies by several researchers have rarely explored which game features inspired young students to learn the language. One of the researcher said in their previous project with colleagues and had identified several game properties which had attracted the attention of 3,945 children in an online English-Learning site in Japan (Tompkins, 2014) by studying their computer play behaviour. These included cognitive difficulties where challenges were integrated (challenge), a stimulation of children's curiosity (mystery), greater control (control), and multiple players (competition).

\section{Research Objectives}

1) To improve the pupils' spelling skill of compound nouns using the Pictoword Game application.

2) To examine pupils' perception in improving spelling skill of compound nouns using the Pictoword Game application.

3) To identify spelling errors in spelling compound words.

\section{Research Questions}

Research questions were designed based on the problem found among the research participants. This action research was carried out to provide answers for the following research questions:

1) Can the pupils' spelling be improved by using the Pictoword application game?

2) To what extent the "Pictoword" application game helps in improving pupil' spelling skill of compound nouns?

3) What is the common spelling errors pupils' make when spelling compound words?

\section{Research Methodology \\ Research Design}

In implementing the research, researcher chose to conduct the intervention based on Kemmis and McTaggart's (1988) action research model. According to Fraenkal (2015), Kemmis and McTaggart had introduced a spiral model, which consists of four important steps in action research, which are plan, act, observe and reflect.

\section{Research Participants}

Research participants for this research comprised of 35 eleven years old pupils. There were nineteen boys and sixteen girls. Researcher addressed them as RP 1 until RP 35. Teacher notified them based on their number in the classroom name list. There were selected due to their low scores compared to other pupils from other classes during the spelling bee activity conducted in the class as well as the mistakes spotted in the writing worksheets given to them during English teaching and learning sessions. The research participants were all Malays and all of them came from families with fair socio - economic backgrounds who lives in an urban area. In addition, they were only familiar with English language in school and they were not using English language in their daily conversation as well as fond listening to English songs or English movies. They tend to put on the Malay subtitles even change the voice over to Malay Language when watching English cartoon. Even in school, the English Panel team and the school administrations need to establish Tuesday as school English Day to encourage them to speak English in school. 


\section{Data Collection Method}

Data was collected through triangulation data method to get more reliable data using qualitative and quantitative. In this action research, researcher decided to use three methods to collect the data throughout the process of intervention. As for the first method, spelling document analysis, then second method was through observation checklist and lastly by using Emoji survey method.

Researcher observed pupils by using a checklist along the session which consists of behaviour and attitude, achievement or the pupils', the teacher could identify their pupils' problem as stated by Bruns (2014) that a checklist is a list of items you need to verify, check or inspect. By using a checklist, it allowed the teacher to ensure that you did not forget any important steps. That means, the checklist provided would be orderly arranged so that the teacher can understand the flows.

Document analyses that researcher used were spelling bee and two crossword puzzle exercise. These works helped to identify the differences of answers from different pupils. Then, researcher could identify which pupils showed the improvements towards spelling. According to Cooper (2008), the exercises are the best way to compare the pupils' works whether they improve or not. Researcher had recorded down the results for each pupil who managed to spell the words correctly in each intervention. Marks were given according to their ability to spell the compound words correctly. The marks only revealed to pupils after each step done not after each compound nouns were spelled because wanted them to still concentrate in the games. The marks were recorded not as comparison with other research participants but as an inference to show their improvement in spelling compound words.

In collecting the emoji survey, researcher conducted a survey after intervention. An Emoji survey was taken into action considering all the research participant were all eleven years old children and through survey, researcher be able to know factors hindering their ability to spell as survey was more casual than a formal conversation (Fraenkel, et al., 2015). Surprisingly, they answered the questions well yet with sincerity thus leading to a valid and reliable data by using attractive Emoji stickers provided by the researcher. Pupils chose the suitable face expression of stickers before sticking those on the answers box.

\section{Findings}

The findings of the research were written based on the three research questions. All the data were collected based on three data collection methods. 
Vol. 9, No. 2, 2020, E-ISSN: 2226-6348@ 2020 HRMARS

Table 1

Instruments and Research Questions

\begin{tabular}{|l|l|}
\hline Research Questions & Instruments Used \\
\hline $\begin{array}{l}\text { Research Question } 1 \\
\text { 1. Can the pupils' spelling be } \\
\text { improved by using the } \\
\text { "Pictoword' application } \\
\text { game? }\end{array}$ & \\
\hline $\begin{array}{l}\text { Research Question } 2 \\
\text { 2. To what extent the } \\
\text { "Pictoword" application } \\
\text { game helps in improving } \\
\text { pupil' spelling skill of } \\
\text { compound nouns? }\end{array}$ & \\
\hline $\begin{array}{l}\text { Research Question 3 } \\
\text { 3. What is the common Survey } \\
\text { spelling errors pupils' make } \\
\text { when spelling compound } \\
\text { words? }\end{array}$ & Spelling Document Analysis \\
\end{tabular}

\section{Spelling Document Analysis and Spelling Errors}

Spelling document analysis was used to answer the Research Question 1: Can the pupils spelling be improved by using the Pictoword Game Application? The use of Pictoword Game Application in improving the participants' ability to spell compound nouns was analysed and by comparing the results of the spelling exercises and progress checks which were completed before by using the Spelling Bee test and after the implementation of the intervention. Then, researcher had specifically chosen to elaborate and showed on their progress to retain their memory from the intervention where pupils were tested their ability to complete twenty out of forty compound words in two crossword puzzles. Furthermore, researcher did an in-depth spelling error analysis to answer the Research Question 3 in this research of: What are the most common spelling errors that pupils made in spelling compound words? Researcher categorised the spelling errors into subcategories then extracted the top 10 misspelled compound words and top 10 of correct spelling compound words before and after the intervention.

The analysis was done to thirty - five pupils' spelling before and after the intervention. In this research, the teacher addressed pupils as research participant 1 to research participant 35 based on their name in the class list name. The document analysis included the worksheet that teacher provided after the intervention. From the observation, the participants showed improvements as compared to the time before the intervention was carried out. The progress could be seen from the worksheets that they did. The comparison of the scores before and after the intervention session is shown in the Table 4.1 below. 
INTERNATIONAL JOURNAL OF ACADEMIC RESEARCH IN PROGRESSIVE EDUCATION AND DEVELOPMENT

Vol. 9, No. 2, 2020, E-ISSN: 2226-6348 @ 2020 HRMARS

Table 2 Comparison of participants' results before and after the intervention.

\begin{tabular}{|c|c|c|}
\hline RESEARCH PARTICIPANT & $\begin{array}{c}\text { BEFORE } \\
\text { INTERVENTION }\end{array}$ & $\begin{array}{c}\text { AFTER } \\
\text { INTERVENTION }\end{array}$ \\
\hline 1 & $34 / 40$ & $39 / 40$ \\
\hline 2 & $34 / 40$ & $40 / 40$ \\
\hline 3 & $32 / 40$ & $40 / 40$ \\
\hline 4 & $24 / 40$ & $38 / 40$ \\
\hline 5 & $29 / 40$ & $39 / 40$ \\
\hline 6 & $30 / 40$ & $40 / 40$ \\
\hline 7 & $20 / 40$ & $37 / 40$ \\
\hline 8 & $23 / 40$ & $39 / 40$ \\
\hline 9 & $24 / 40$ & $39 / 40$ \\
\hline 10 & $16 / 40$ & $40 / 40$ \\
\hline 11 & $30 / 40$ & $40 / 40$ \\
\hline 12 & $26 / 40$ & $40 / 40$ \\
\hline 13 & $31 / 40$ & $39 / 40$ \\
\hline 14 & $17 / 40$ & $37 / 40$ \\
\hline 15 & $14 / 40$ & $39 / 40$ \\
\hline 16 & $34 / 40$ & $39 / 40$ \\
\hline 17 & $28 / 40$ & $38 / 40$ \\
\hline 18 & $21 / 40$ & $40 / 40$ \\
\hline 19 & $26 / 40$ & $40 / 40$ \\
\hline 20 & $32 / 40$ & $40 / 40$ \\
\hline 21 & $20 / 40$ & $40 / 40$ \\
\hline 22 & $26 / 40$ & $40 / 40$ \\
\hline 23 & $31 / 40$ & $40 / 40$ \\
\hline 24 & $27 / 40$ & $38 / 40$ \\
\hline 25 & $33 / 40$ & $40 / 40$ \\
\hline 26 & $35 / 40$ & $39 / 40$ \\
\hline 27 & $28 / 40$ & $40 / 40$ \\
\hline 28 & $23 / 40$ & $40 / 40$ \\
\hline 29 & $32 / 40$ & $40 / 40$ \\
\hline 30 & $25 / 40$ & $37 / 40$ \\
\hline 31 & $31 / 40$ & $38 / 40$ \\
\hline 32 & $32 / 40$ & $38 / 40$ \\
\hline 33 & $33 / 40$ & $39 / 40$ \\
\hline 34 & $9 / 40$ & $37 / 40$ \\
\hline 35 & $14 / 40$ & $39 / 40$ \\
\hline
\end{tabular}

Based on the findings above, the before intervention activity was the spelling bee test and the after intervention activity was the Pictoword Games answers from level 1 until level 40 from the application. The score showed improvement between the before intervention and after 
intervention. As we can see, some of them showed vast improvement in their spelling exercises to full scored 40 out of 40 but nineteen pupils were unable to get full marks. The most impressive research participant is RP34, which the boy only obtained, scored of 9/40 in the spelling bee but managed to elevate his scores to $37 / 40$ after using the intervention compared to the spelling bee test. This went the same with RP35 whom scores was below 15 and he managed to get 39/40 compared to the first spelling test. As for RP26, even he managed to get almost full score in spelling bee test with 35/40 unfortunately he was unable to even obtain 40/40 during the intervention. From the table, researcher can conclude that six research participants who are RP13, RP16, RP26, RP31, RP32 and RP33 still unable to obtain full score even they got thirty and above correct answers during the spelling bee test nevertheless they were still improving and none of the research participants scored below their first activity.

For the first activity of Spelling Bee, they were unable to spell correctly and to get full score for all the words. At this point, researcher could say that they were still unable to combine two meaningful words. However, they improved a lot when been introduced to the Pictoword Game application, which was the focused intervention. In order to retain their genuine score, two crossword puzzles consisted half of the compound words were tested. They were given meaning of the words as clues to ensure they understand the usage of those words.

The massive changes in all the thirty five research participants' score after the intervention had paved the way towards showing significance answer to the Research Question 1. It could be concluded that the research participants' spelling compound nouns skill did experience the improvement.

Directed to answer the third Research Question 3 : What is the most common spelling errors that pupils made in spelling compound words? Researcher categorised the spelling errors into subcategories then extracted the top 10 misspelled compound words and top 10 of correct spelling compound words before and after the intervention as below.

The results in Table 4.3 below shows the frequency and the percentages of spelling errors based on 35 students written spelling document analysis according to the eleven subcategories by James (1998). Researcher first confronted the spelling errors categorised by Cook (1999). Somehow the four categories mentioned by him which were omission, insertion, substitution and transposition are too general to sort the errors out. Furthermore, James eleven spelling errors categories are most likely to be suitable to be extracted for written essay spelling errors where the types of error can be numerous but it also can be done to detect spelling errors during the spelling activities in the classroom. Despite of the data sample used in this research is limited, researcher was being able to scan and skim the errors more thoroughly to sort them in the suitable categories based on the supported existing literature which are omission, replacement, addition, mis - ordering, L1 influence, word coinage, doubling, US spelling, mis - use of punctuation, mis - pronunciation and direct borrowing. The researcher analysed the error categories along with the examples of errors from the research participants' document analysis 
INTERNATIONAL JOURNAL OF ACADEMIC RESEARCH IN PROGRESSIVE EDUCATION AND DEVELOPMENT

Vol. 9, No. 2, 2020, E-ISSN: $2226-6348$ @ 2020 HRMARS

into Table 4.3. The examples were typed according to the original written from the spelling document received.

Table 3 Categories and examples of spelling errors

\begin{tabular}{|c|c|c|}
\hline Categories of errors & Pupils' spelling & Actual Word \\
\hline Omission & $\begin{array}{c}\text { Honeycom } \\
\text { Keybord } \\
\text { Dorbell } \\
\text { Sutcase }\end{array}$ & $\begin{array}{c}\text { Honeycomb } \\
\text { Keyboard } \\
\text { Doorbell } \\
\text { Suitcase }\end{array}$ \\
\hline Replacement & $\begin{array}{c}\text { Linestone } \\
\text { Honeycome } \\
\text { Watermalon } \\
\text { Wabmail } \\
\text { Doorball }\end{array}$ & $\begin{array}{c}\text { Limestone } \\
\text { Honeycomb } \\
\text { Watermelon } \\
\text { Webmail } \\
\text { Doorbell }\end{array}$ \\
\hline Addition & $\begin{array}{c}\text { Wartermelon } \\
\text { Suitecase } \\
\text { Brainbow } \\
\text { Tableclothe }\end{array}$ & $\begin{array}{c}\text { Watermelon } \\
\text { Suitcase } \\
\text { Rainbow } \\
\text { Tablecloth }\end{array}$ \\
\hline Mis - Ordering & $\begin{array}{c}\text { Keybroad } \\
\text { Stopwacth } \\
\text { Watermolen } \\
\text { aerring } \\
\end{array}$ & $\begin{array}{c}\text { Keyboard } \\
\text { Stopwatch } \\
\text { Watermelon } \\
\text { Earring }\end{array}$ \\
\hline L1 - influence & $\begin{array}{c}\text { Selphone } \\
\text { Cellfon } \\
\text { Aisbox }\end{array}$ & $\begin{array}{c}\text { Cellphone } \\
\text { Cellphone } \\
\text { Icebox }\end{array}$ \\
\hline Word Coinage & $\begin{array}{c}\text { Swartfish } \\
\text { Neckles } \\
\text { Whabmeal } \\
\text { chakbook }\end{array}$ & $\begin{array}{l}\text { Swordfish } \\
\text { Necklace } \\
\text { Webmail } \\
\text { checkbook }\end{array}$ \\
\hline Doubling & $\begin{array}{c}\text { Horseshooe } \\
\text { Icebox } \\
\text { Jumproope } \\
\text { teasspoon }\end{array}$ & $\begin{array}{l}\text { Horseshoe } \\
\text { Icebox } \\
\text { Jump rope } \\
\text { Teaspoon }\end{array}$ \\
\hline Mis - pronunciations & $\begin{array}{l}\text { Beenbag } \\
\text { Binbag } \\
\text { Sendwish } \\
\text { tableclock }\end{array}$ & $\begin{array}{c}\text { Beanbag } \\
\text { Beanbag } \\
\text { Sandwich } \\
\text { Tablecloth } \\
\end{array}$ \\
\hline Direct borrowing & $\begin{array}{c}\text { Tispoon } \\
\text { Lipstik } \\
\text { Eardram } \\
\text { Suitkase }\end{array}$ & $\begin{array}{l}\text { Teaspoon } \\
\text { Lipstick } \\
\text { Eardrum } \\
\text { Suitcase }\end{array}$ \\
\hline
\end{tabular}

Figure 1 Top 10 most misspelled compound words before intervention 


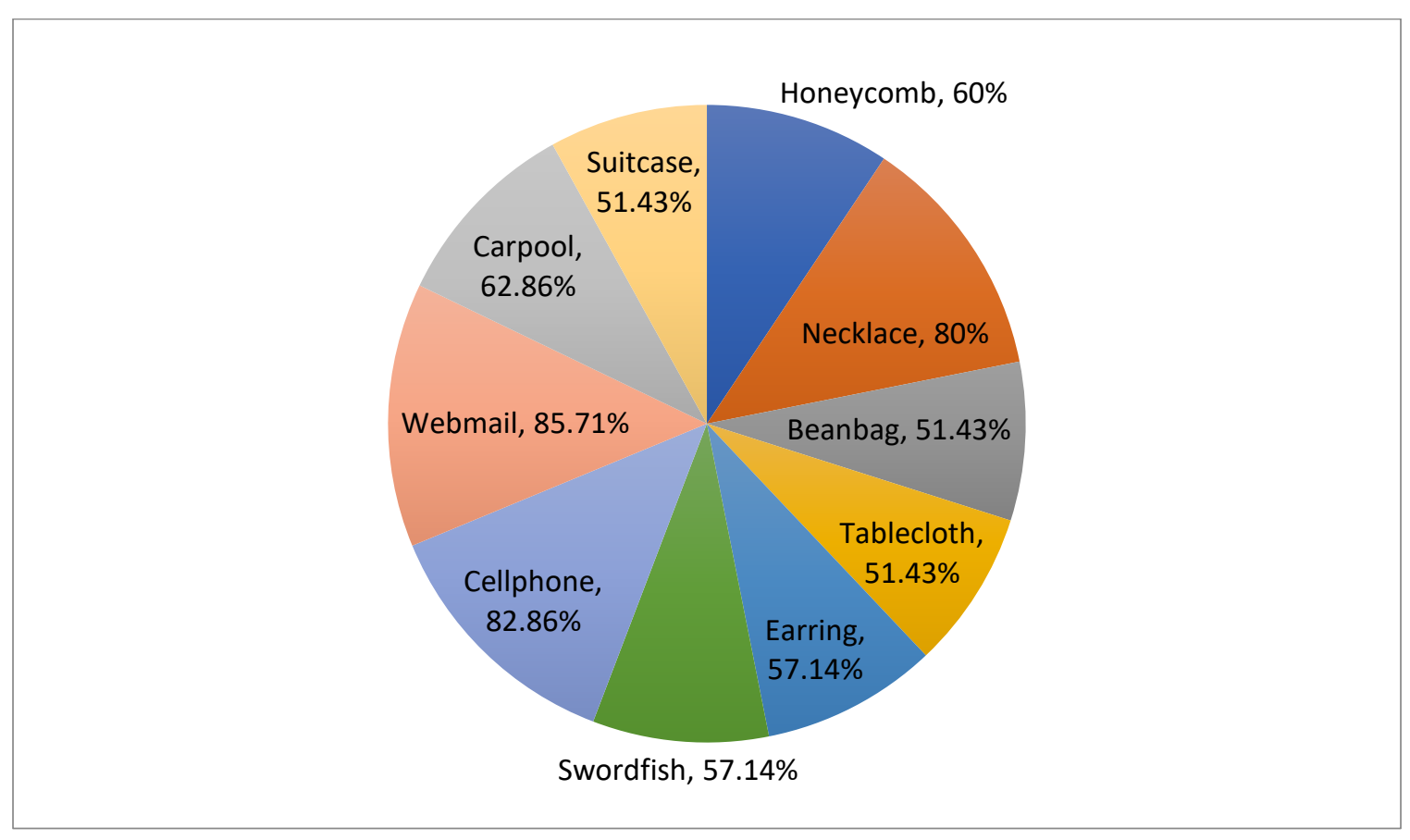

The most misspelled word is Webmail as 30 pupils (82.86\%) misspelled the word. Many pupils mis pronunciated the word made it turned out to wabmeal, webmill and wheatmeal. They were motivated to spell with existing English words but when both words combined it was not a meaningful compound word. The second misspelled word is cellphone. From the spelling errors categories the compound word of cellphone falls into two categories. Those are L1 influence and mis - pronunciations. Extracted from the documents, 23 out of 29 pupils spelled Cellphone as Selphone, Cellfon and Selfon. Sel is a Malay word means cell and fon is for phone. Both of the Malay words are phonetically sound similar to the L2. Twenty-eight pupils misspelled necklace followed after 21 pupils made errors honeycomb. Most of the pupils substitute another letter to combine with the word neck and some of them also coinage it with other letters to make it sound similar for example to neckless, necklass and neckclass while for the honeycomb, most pupils omit a letter $b$ at the end of the word to make it into honeycomb. In addition, the word beanbag also misspelled as they heard their teacher pronounced it differently. Pupils thought the actual words are binbag or beenbag. Pupils tend to spell the word without knowing its meaning but they urged to spell according to how it sounds. 
INTERNATIONAL JOURNAL OF ACADEMIC RESEARCH IN PROGRESSIVE EDUCATION AND DEVELOPMENT

Vol. 9, No. 2, 2020, E-ISSN: 2226-6348 @ 2020 HRMARS

Figure 2 Top 10 most correct spelling of compound nouns before intervention

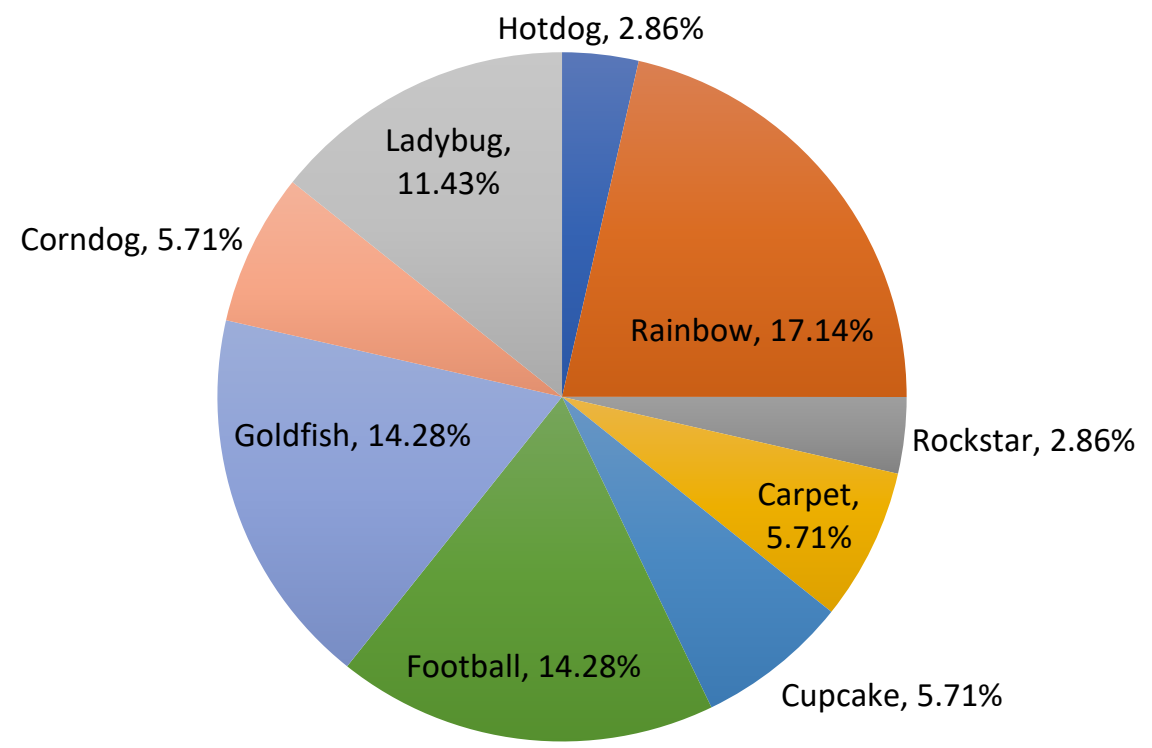

From the figure, researcher can conclude that these ten words are familiar with the age of the research participants, which are in the range of 10 to 11 eleven years old. For example, hotdog, cupcake and corndog are light meal that they always eat. During the research period, corndog that originally a Korean styled food with $5.71 \%$ only two pupils got it wrong due to it is currently viral all over the places and the pupils knew about these foods from the social media. Moreover, ladybug, goldfish and jellyfish are animals, which they were familiar since kindergarten as introduction to know basic English words. Five pupils misspelled football even it is one of the famous sports in the world and in school none other than because they substitute or omit a letter might be due to anxiety and overconfident as they misspelled to foodball and footbal.

Figure 3 Two pictures shown from five compound words of the Pictoword Game application

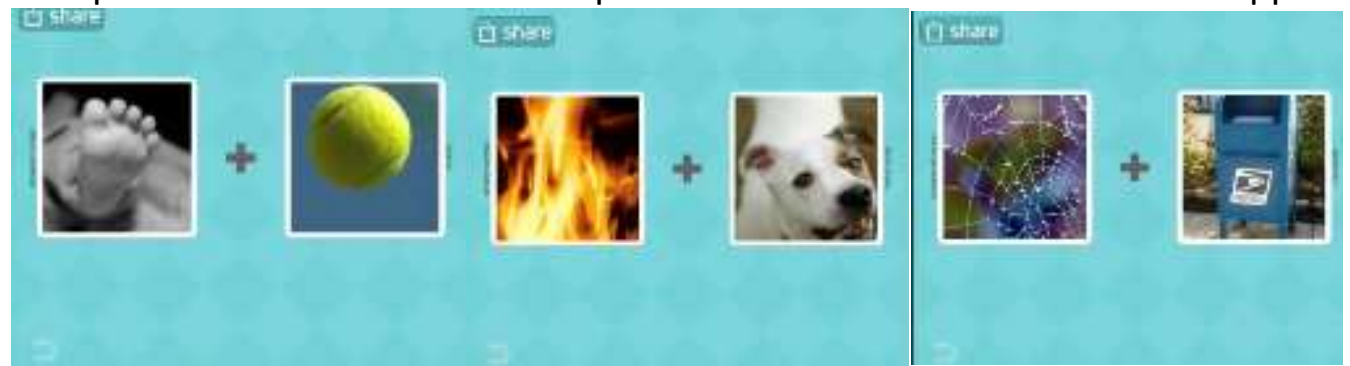


Vol. 9, No. 2, 2020, E-ISSN: 2226-6348@ 2020 HRMARS

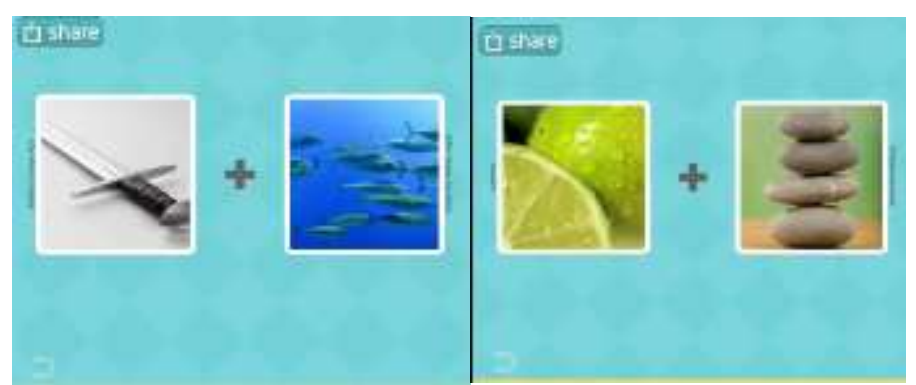

Table 4 Replacement words that pupils did during the intervention

\begin{tabular}{|l|l|l|}
\hline Categories of errors & Actual Compound Word & Pupils' spelling \\
\hline Replacement & Football & Legball \\
& Hotdog & Firedog \\
& Webmail & Website \\
& Swordfish & Knifefish \\
& Limestone & Lemonrock \\
& & Lemonstone \\
& & Limerock \\
\hline
\end{tabular}

From the figure and the table, researcher can conclude that this activity referred to the cognitive theory. Pupils learn those pictures, as their input then the output will be the words they remembered when they learnt recognise the pictures mean. As example, pupils saw the picture of fire so he automatically spelled fire + dog unconsciously realised it is not a compound word. Hence, it is the same for the picture of football which the pupil saw the picture as leg + ball. In addition, some of the pictures were not familiar to Malaysian culture where in Malaysia, the postbox supposed to be red in colour but the picture shown blue. Furthermore, in Malaysian education system, pupils do not learn how to differentiate between rock, stone and pebbles. They were considering the same words and meanings. Therefore, eight pupils misspelled lime + stone to lemonrock, lemonstone and even lime rock

Table 5 Mis ordering words that pupils did during the intervention

\begin{tabular}{|l|l|l|}
\hline Categories of errors & Actual Compound Word & Pupils' spelling \\
\hline Mis ordering & Stopwatch & Stopwacth \\
& Handshake & Handshaek \\
& Watermelon & Watermolen \\
& Swordfish & Sowrdfish \\
& Keyboard & Keybroad \\
\hline
\end{tabular}

Next spelling error category to be discussed is the mis ordering. Mis ordering letters means pupils reverse the letters. Three out of five pupils misspelled these words were actually spelled correctly during the spelling bee activity. This can be concluded as they were making careless mistakes and did not recheck their answers first. 
Vol. 9, No. 2, 2020, E-ISSN: 2226-6348 @ 2020 HRMARS

In conclusion, spelling errors during the intervention were $88.72 \%$ improved. This showed that the Pictoword Game application showed vast improvement on pupils in spelling compound nouns.

\section{Observation}

The second research question : To know the perception of pupils toward the Pictoword Game application in improving pupil's spelling skill of compound nouns will be answered and analyzed using the observation and survey method. The analysis of pupils observation will be specifically done by explaining what the teacher had seen before and after the intervention session with the help of observation checklist that consists of behaviour, attitudes, achievements and pupils' participation throughout before and after the intervention

Table 6 Observation Checklist

\begin{tabular}{|c|c|c|c|c|c|c|c|c|c|c|}
\hline \multirow[t]{2}{*}{ Aspects } & \multicolumn{3}{|c|}{$\begin{array}{l}\text { Before } \\
\text { Participants) }\end{array}$} & \multicolumn{2}{|c|}{ (Research } & \multicolumn{3}{|c|}{$\begin{array}{l}\text { After } \\
\text { Participants) }\end{array}$} & \multicolumn{2}{|c|}{ (Research } \\
\hline & 10 & 14 & 15 & 34 & 35 & 10 & 14 & 15 & 34 & 35 \\
\hline \multicolumn{11}{|l|}{ Behaviour and attitude } \\
\hline 1. Talking with other pupils & I & I & $X$ & $X$ & I & / & I & I & I & I \\
\hline 2. Disturbing other pupils & I & I & $\mathrm{X}$ & $\mathrm{X}$ & I & $\mathrm{X}$ & I & $\mathrm{X}$ & $\mathrm{X}$ & I \\
\hline 3. Good discipline & I & $X$ & I & I & $X$ & / & I & I & I & I \\
\hline $\begin{array}{l}\text { 4. Listen attentively to } \\
\text { teacher's explanation }\end{array}$ & $\mathrm{X}$ & / & / & $x$ & $x$ & / & I & / & I & I \\
\hline $\begin{array}{l}\text { 5. Respond to teacher's } \\
\text { questions }\end{array}$ & $x$ & / & / & $x$ & $x$ & / & / & $x$ & / & / \\
\hline $\begin{array}{l}\text { 6. Show appropriate body } \\
\text { language to show } \\
\text { understanding }\end{array}$ & $x$ & / & $x$ & $x$ & $\mathrm{X}$ & / & I & / & / & I \\
\hline 7. Asking questions & $x$ & / & $x$ & $x$ & / & / & / & / & / & / \\
\hline \multicolumn{11}{|l|}{ Achievement } \\
\hline $\begin{array}{l}\text { 8. Improving in spelling } \\
\text { compound nouns }\end{array}$ & $x$ & $x$ & $x$ & $x$ & $x$ & / & / & / & / & / \\
\hline 9. Recognize the pictures & $x$ & / & $x$ & / & / & / & / & / & / & / \\
\hline 10. Complete the tasks given & $x$ & $x$ & $x$ & $x$ & $x$ & / & / & / & / & / \\
\hline \multicolumn{11}{|l|}{ Pupils' participation } \\
\hline 11. Actively involved & $x$ & l & $X$ & $X$ & I & / & / & I & / & / \\
\hline 12. Shy & $x$ & $x$ & / & I & $X$ & $x$ & $x$ & I & l & $x$ \\
\hline 13. Uncontrolled & I & $x$ & $x$ & I & I & $X$ & I & $x$ & $X$ & I \\
\hline
\end{tabular}


Based on the observation during the introduction session before the implementation of intervention took place, RP15 and RP34 were among the pupils that looked nervous and worry when the teacher asked him to spell words. The teacher even had to repeat the same questions to them as if they ignored the instructions and did not want to spell the words Even the teacher had difficulties to identify whether they were ready for the lesson as they did not show any respond and show appropriate gestures to show understanding.

However, the responses of the pupils changed after they involved in the intervention of Pictoword Game. They were happy and contented, as they were able to spell the words correctly as their achievement in this intervention activity. They started to show confidence when they were able to recognise the pictures and in jovial when they got to spell the words correctly. They started to realise that compound nouns were combination of two nouns and a picture, which made it easier for them to spell compound nouns by remembering the combination pictures that represent each compound noun.

RP15 was quite reserved but she showed interest in the activity even she did not understand what it was all about and need teacher's extra attention. She started to gain confidence when she was able to spell words 'Football' correctly as she thought foot was food in the spelling bee activity. She was smiling and even showed gestures of excitement when she saw the pictures of a ball and a foot. She then realised the correct word is Football. She started to progress well afterwards. She responded to all teacher's command well and started to mingle with other participants. Even she was unable to get perfect score, which she got 39 in the final exercises, she showed vast improvements throughout the intervention as before intervention she only scored 14 marks. She even asked for teacher to continue with other compound words even the session was ended as she said she wanted to redeem herself and try it again.

\section{Emoji Survey}

The research participants' perception concerning the Pictoword Game application can be proven in the survey that had been conducted. From the survey, perceptions of the pupils could be seen from what they said. The data collected from the survey was transcribed and converted into a descriptive statistics indicating several important aspects. Researcher decided to use the guided questions that prepared and integrated the use of Emoji, which participants can use Emoji stickers to paste in the answers box, provided. Emoji stickers indicated their feelings towards the survey questions asked.

Among all the 9 items, the individual value of item no 9 deviated the most from their relative mean $(S D=1.031)$ and its mean was $(\bar{x}=3.77)$. Apart from that, the lowest deviation from the mean was item $5(S D=0.543)$ due to its mean of $(\bar{x}=4.64)$. From the descriptive analysis, the respondent chose the appropriate Emoji stickers on the scale of 1 and maximum scale of 5. 
Vol. 9, No. 2, 2020, E-ISSN: 2226-6348 @ 2020 HRMARS

Table 7 The participants' perception on using the application

\begin{tabular}{|l|l|c|c|}
\hline No & Items & $\begin{array}{l}\text { Mean, } \\
\bar{X}\end{array}$ & $\begin{array}{l}\text { Std Deviation, } \\
\text { s }\end{array}$ \\
\hline 1 & $\begin{array}{l}\text { How would you rate your satisfaction using Pictoword } \\
\text { Application Game? }\end{array}$ & 3.94 & 3.91 \\
\hline 2 & $\begin{array}{l}\text { How would you rate your satisfaction with the design of the } \\
\text { application? }\end{array}$ & 0.838 & 0.507 \\
\hline
\end{tabular}

Table 8 The respondents' perception on using the spelling game application in improving spelling compound words

\begin{tabular}{|l|l|c|c|}
\hline No & Items & $\begin{array}{l}\text { Mean, } \\
\bar{X}\end{array}$ & $\begin{array}{l}\text { Std Deviation, } \\
\text { s }\end{array}$ \\
\hline 3 & $\begin{array}{l}\text { Do you like to learn spelling using Pictoword Game } \\
\text { application? }\end{array}$ & 4.54 & 0.611 \\
\hline 4 & $\begin{array}{l}\text { What is your feeling when you are able to spell compound } \\
\text { nouns correctly? }\end{array}$ & 4.14 & 0.845 \\
\hline 5 & $\begin{array}{l}\text { Do you think you are getting better in spelling compound } \\
\text { words after been introduced to Pictoword Game? }\end{array}$ & 4.64 & 0.543 \\
\hline
\end{tabular}

Table 9 The respondents' perception on using the application in spelling

\begin{tabular}{|l|l|c|c|}
\hline No & Items & $\begin{array}{l}\text { Mean, } \\
\bar{X}\end{array}$ & $\begin{array}{l}\text { Std Deviation, } \\
\text { s }\end{array}$ \\
\hline 6 & Competitiveness among friends & 4.51 & 0.612 \\
\hline 7 & Simple and interesting pictures & 4.06 & 0.725 \\
\hline 8 & Easy to play and fun & 4.34 & 0.639 \\
\hline 9 & Saved time to spell the words & 3.77 & 1.031 \\
\hline
\end{tabular}

In conclusion, participants excited the most about the Pictoword game application because they can compete with their friends in enable them move on to the next level. They were excited to be the first to complete the game Moreover, pupils also found out the application offered interesting pictures to retention their previous knowledge of basic vocabulary. In addition, the game also easy to play where pupils able to self-play it without been monitoring by adults. However, as it indicated the lowest mean of 3.77 from all the items asked in the survey. Accumulated of only 132 points, four participants chose that the game application did not save time for them to spell the words. They thought the pictures given made them thought more to figure out the correct answer.

\section{Discussions and Reflection}

Reflect from the research question 1 "Can the pupils' spelling be improved by using the "Pictoword Game?" After analysing the data, I found out that the use of "Pictoword Game" to teach spelling was a good technique to teach spelling unlike the traditional method where pupils were required to memorise but it was done by simply playing game. The pupils were no longer bound to the traditional method, which required them to memorise the word to spell correctly. 
Now, they can learn spelling through games that is enjoyable and at the same time more relaxing. Hence, the pupils would be able to learn better through this method.

Even though memorization was not emphasized during the intervention, the pupils would be able to remember the spelling as the pictures given drilled them. They would be required to spell the letters during the game till they could spell the word correctly before can move up to the next level, and able to fill in the spelling in the exercises given after the intervention.

On the other hand, to reflect from the research question 2, "To what extent the "Pictoword Game" helps in improving pupil' spelling skill of compound nouns?" The use of Pictoword Game did in fact increase the research participants' confidence level in when it comes to spelling. The pupils were no longer scared or nervous when it came to spelling. The pupils also could spell without mumbling or stuttering even when they were wrong. This was proven by good achievement gained by participants B who had shown the improvement throughout the intervention. This accomplishment in line with Krashen's theory of second language acquisition as Krashen cited in Schutz (2014) claimed that low motivation, low self - esteem and debilitating anxiety can combine to raise the affective filter and form a 'mental block' that prevents comprehensible input from being used for acquisition. Surprisingly, the pupils also became more independent over the span of time the intervention was carried out. Through Vygotsky's Scaffolding Theory, which emphasizes on the Zone of Proximal Development, I had to provide total support during the first session. The support however decreased as more sessions were carried out. Pupils were able to complete the intervention on their own with only minimum guidance was required during the last session. This was mainly because the pupils were trying to do it by themselves and talking to themselves more to acquire the spelling skills.

Furthermore, research question 3: What is the common spelling errors pupils' make when spelling compound words? Had been reflected by students learning with colorful pictures had various advantages in dealing with memory retention. Wichman, Sharpe and Gegenfurtner (2012) as cited in Mariam and Faiz (2013) supported the statement by indicating that the colour acts as a powerful information channel to the human cognitive system, and has been found to play a significant role in enhancing memory performance. Hence using this Pictoword game, which I incorporated with various colourful pictures, I could say that it helped them in improving their spelling skill in terms of reproducing the spelling by looking at the pictures to trigger their memory. Besides they were now able to write the spelling words as well as spelling the words orally too.

In addition, the positive response from the participants as well as their active participations throughout the session had clearly lead to the change in their perception towards spelling activities after using Pictoword game. All of them agreed that spelling activities were no longer distressing after been involved with the game. In fact, they liked the Pictoword game as it inculcated the elements of games throughout the activities. Despite making it enjoyable, it also created a non - threatening environment especially for primary school pupils. This was due to children are in born with their instinct towards playing. Brumfit (1995) as cited in Nova (2010) 
said, "Children play and children want to play. Children learn through playing, children interact and in interacting they develop language". Hence, I as the teacher reflected this as an advantage for me in manipulating the element of play and games to ensure better grasp of the language among the pupils.

\section{Conclusion}

Nevertheless, it is important to stress that the success of a spelling system depends on the expectations and enthusiasm of learner. The students in this study enjoyed creating images of words; thus it is an important requirement for any subject that students need to learn to sustain their motivation and excitement (Bosman et al., 2006). However, (Sawyer et Joyce, 2005) researchers contend that the spelling of the consciousness may be accelerated by restricting teaching to appropriate and essential skills. They stress learners' development. This can be done by activities, such as creative writing, structuring assignments so that students can excel, showing how necessary it is to clearly write out in the realistic and social situations, providing the instructor opportunity for immediate feedback and self-correction and translating knowledge into other language arts.

Participants had given their positive feedback regarding this game; researcher would suggest that this activity of Pictoword to be carried out with other passive pupils. Seeing positive changes in my participant attitude where they are much confident to attend their English classes after the intervention session, it had given me the perception that it can also do the same to other passive pupils. Besides, this game not only caters for limited words at a time, it can be extended to more words by completing the levels. Teacher also can widen the scope of the word class and it does not solely focused on compound nouns. Since it's a game with leveled up, it also can be a good tool to ensure pupils' ability is challenged and they can broaden their spelling skills with other words as well. In a way, it can also be included with a few high frequency words to take them out of their comfort zone. Researcher also believed by adding more words to the book, it will also provide pupils with a longer time to play. Since this game is a hands-on activity, it will be a good one for experiential learning where pupils learn by doing it and reflecting the experience.

Furthermore, improvement that can be made to the intervention is by changing the format of the intervention. Researcher carried out the intervention individually. The participants were not required to communicate or discuss with each other. However, researcher could change the format into pair activity instead of the individual especially during the earlier session as they were not confident and peer guidance would have made the situation better. Pair activity could enable the participants to help each other and at the same time to be more confident as they have a peer to back them up.

Lastly, recommendation for future research requires the continuing experimentation in study of spelling issues in all mother tongues for learners with orthodoxies and the potential application to visual imagery to mitigate the spelling difficulties of those learning with other impairments. In conclusion, this research does not dispute the significance of informal and incidental methods in 
Vol. 9, No. 2, 2020, E-ISSN: $2226-6348$ @ 2020 HRMARS

spell learning; nevertheless it supports further studies which show that primary students benefit from direct spelling guidance. Only coping with spelling as a minor aspect of writing processes.

\section{References}

Bahagian Pembangunan Kurikulum. (2011). Dokumen Standard Kurikulum Sekolah Rendah: Bahasa Inggeris Tahun 4 [Standard Curriculum Document: English Year 4]. Putrajaya: Kementerian Pelajaran Malaysia.

Byrnes, B. (2001). Second Edition. Cognitive Development and Learning in Instructional Contexts. Allyn and Bacon: Needham Heights, M.A.

Bosman, A. M. T., van Hell, J. G., \& Verhoeven, L. (2006). Learning the spelling of strange words in Dutch benefits from regularized reading. Journal of Educational Psychology, 98, 879-890.

Botley, S., and Dillah, D. (2016). Investigating spelling errors in a Malaysian learner corpus. Malaysian Journal of ELT Research, 3(1): 74-93.

Burns, A. (2005). Collaborative action research for English language teachers. Cambridge: Cambridge University Press.

Carreker, S. (2005). Teaching spelling. In J. Birsh (Ed.), Multisensory teaching of basic language skills ( $2^{\text {nd }}$ Edition)/ pp. 257-295. Baltimore, Md.: Paul Brookes.

DuBois, K., Erickson, K., \& Jacobs, M. (2007). Improving spelling of high frequency words for transfer in written word (Doctoral dissertation). Educational Resources Information Centre.

Sigridur, D. (2012). The Use of Games in The Language Classroom. Retrieved from http://skemman.is/stream/get/1946/6467/13457/1/Sigridurdogg2010.pdf.

Dzulkifli, M., \& Mustafar, M. F. (2013). The Influence of Colour on Memory Performance: A Review. The Malaysian Journal of Medical Sciences: MJMS. 20. 3-9.

Fraenkel, J. R., Wallen, N. E. \& Hyun, H. H. (2015). How to design and evaluate research in education (9th ed.). New York: McGraw-Hill Education.

Gardner, H. (2004). The disciplined mind: What all students should understand. New York: Simon \& Schuster.

Ghabool, N., \& Kashef, S. H. (2012). Investigating Malaysian ESL Students' Writing Problems on Conventions, Punctuation, and Language Use at Secondary School Level. Journal of Studies in Education, 2(3), 130-143.

Harmer, J. (2007). The practice of English language teaching. Harlow, England: Pearson Longman. Holton, D., \& Clarke, D. (2006). Scaffolding and metacognition. International Journal of Mathematical Education in Science and Technology, 37(2): 127-143.

Lesley L. (2011). Exposure to Misspellings Confuses Spelling Proficiency. In decoded science. Retrieved from http://www.decodedscience.com/exposure-to-misspellings-confusesspellingproficiency/6104

Mamour, C. T. (2008). The relevance and implications of Vygotsky's sociocultural theory in the second language classroom. ARECLS, 5: 244-262.

Ministry of Education. (2012). Malaysia Education Blueprint 2013-2025. Preliminary ReportExecutive Summary: Putra Jaya Malaysia: Malaysia Government.

Miller, L., \& Pound, L. (2010). Theories and Approaches to Learning in the Early Years. London: SAGE Publications.

Mohamed, A. (2007). Kelemahan Berbahasa Inggeris membimbangkan. Utusan. 
Diana, N. P. R. (2010). The Advantages and Disadvantages of Using Games in Teaching Vocabulary to the Th ird Graders of Top School Elementary School. Indonesia: Sebelas Maret Universiti.

Prensky, M. (2002). Not only the lonely: implications of "social" online activities for higher education. On the Horizon, 10(4).

Sawyer, D., \& Joyce, M. (2005). Research in Spelling: Implications for Adult Basic Education. Review of Adult Learning and Literacy. 6. 10.4324/9781410617330.

Schutz, R. (2014). Stephen Krashen's Theory of Second Language Acquisition. Retrieved from http://sk.com.br/sk-krash.html

Sylvan, L. (2012). $1^{\text {st }}$ Grade Spelling Games and Activities. Random House Children Books.

Templeton, S. (2002). Spelling, logical, lernable and critical. ASHA Leader, 7(3), 4-7.

Tompkins, G. E. (2014). Literacy for the 21st century: A balanced approach. Boston, MA: Pearson.

Wichman, F. A., Sharpe, L. T., Gegenfurtner, K. R. (2012). The contribution of colour to recognition memory for natural scenes. J Exp Psychol Learn, 28(3): 509-520.

Westwood, P. (2014) Teaching Spelling: exploring commonsense strategies and best practices. New York, NY: Routledge.

Wood, S. (2015). A Brief History of the Book - Art and Books Website - Charles Sturt University.Csu.edu.au. 